\title{
Physical activity as a pro-health behaviour in the opinion of adult women
}

Authors' Contribution:

A Study Design

B Data Collection

C Statistical Analysis

D Data Interpretation

E Manuscript Preparation

F Literature Search

G Funds Collection
Maria Lipko ABCF, Anna Darmas DEG

Faculty of Tourism and Recreation, Josef Pilsudski University School of Physical Education in Warsaw, Poland

\section{abstract}

Background This study aims at determining opinion of participants of strengthening and relaxation classes on health determinants and their influence on adoption of particular forms of physical activity.

Material/Methods

Participants of the study were 113 women aged 40 to 55, among whom 70 participated in such strengthening and relaxation courses as yoga, Pilates and Tai Chi and 43 women were inactive (control group). A survey prepared by the authors of this paper was used.

Results According to the participants, the most crucial factors influencing health are proper nutrition, adoption of physical activity and keeping proper body weight. Active women are aware of beneficial effects of regular physical activity, in particular regarding improvement of their mobility. Participants of strengthening and relaxation classes proclaim that physical activity drove them to a "healthy lifestyle" and especially to healthy nutrition habits. They recognise a pro-health meaning of physical activity, particularly in order to preserve fitness in the old age.

Conclusions Participants of the classes are aware of a pro-health value of regular participation in strengthening and relaxation courses. Pro-health policy of every country should strive to raise awareness of beneficial influence of regular physical activity and proper dietary behaviours on health status.

Key words physical activity, fitness, pro-health behaviours, strengthening exercises, relaxation exercises.

\section{article details}

Article statistics

Full-text PDF:

Copyright

Indexation:

Funding:

Conflict of interest: Corresponding author:

Open Access License:
Word count: 3,982; Tables: 7; Figures: 0; References: 48

Received: September 2014; Accepted: May 2015; Published: June 2015

http://www.balticsportscience.com

(c) Gdansk University of Physical Education and Sport, Poland

Celdes, CNKI Scholar (China National Knowledge Infrastructure), CNPIEC, De Gruyter - IBR (International Bibliography of Reviews of Scholarly Literature in the Humanities and Social Sciences), De Gruyter - IBZ (International Bibliography of Periodical Literature in the Humanities and Social Sciences), DOAJ, EBSCO - Central \& Eastern European Academic Source, EBSCO - SPORTDiscus, EBSCO Discovery Service, Google Scholar, Index Copernicus, J-Gate, Naviga (Softweco, Primo Central (ExLibris), ProQuest - Family Health, ProQuest - Health \& Medical Complete, ProQuest - Illustrata: Health Sciences, ProQuest - Nursing \& Allied Health Source, Summon (Serials Solutions/ProQuest, TDOne (TDNet), Ulrich's Periodicals Directory/ulrichsweb, WorldCat (OCLC)

This research received no specific grant from any funding agency in the public, commercial, or not-for-profit sectors.

Authors have declared that no competing interest exists.

Maria Lipko, Faculty of Tourism and Recreation, J. Pilsudski University School of Physical Education in Warsaw, Poland Marymoncka 34 Str., 00-968 Warsaw; e-mail: maria.lipko@awf.edu.pl

This is an open access article distributed under the terms of the Creative Commons Attribution-Non-commercial 4.0 International (http://creativecommons.org/licenses/by-nc/4.0/), which permits use, distribution, and reproduction in any medium, provided the original work is properly cited, the use is non-commercial and is otherwise in compliance with the license. 


\section{INTRODUCTION}

According to the World Health Organization, preventive health care is one of three realms of medical science and it encompasses three levels: primary, secondary and tertiary prevention. Physical activity, being a preventive measure for numerous diseases of the 21 st century, is a vital part of its two first stages. Primary preventive healthcare aims at reinforcing appropriate health-enhancing behavioural patterns - a healthy lifestyle - and preventing the spread of health-compromising behaviours among healthy people. Its objective is to reduce the number of cases of disease through reduc-ing the disease risk [1]. Secondary prevention means interventions taken to prevent disease conse-quences through early detection and treatment. At this stage, it is of utmost importance to detect the disease prior to the occurrence of its symptoms or when they are not very visible yet. Another vital point constitutes health culture of the society, which is closely correlated with physical activity. Taking appropriate measures in both primary and secondary preventive health care can significantly contribute to raising health awareness of the society [1].

The current prevalent lifestyle includes many stress factors which increasingly lead to discomfort and in particular to reduction in the quality of life. Various forms of physical activity such as types of yoga, Pilates and tai chi boost people's well-being. Health determinants, which influence subjective feeling of comfort, can be defined while scrutinising participants' opinions on their well-being. Studies can verify a health-enhancing influence of these courses, especially in early prevention. The above-mentioned forms of physical activity are crucial for people in danger of non-communicable diseases, in particular in danger of chronic fatigue, stress and depression, as they require high precision, striving for balance and reuniting body and mind [2]. This is most visible in yoga classes, as yoga shapes strong will and reinforces the sense of unity of body, soul and mind. It shows participants the strength and possibilities of the body and teaches them to trust themselves. It brings harmony, calmness and inner peace [3]. Thus, such courses have a significant pro-health impact. Pilates exercises, which are focused on strengthening muscles, in particular abdominal muscles [4], back muscles, shoulder girdle muscles and pelvis muscles, reduce back pain. Tai chi exercises, which do not significantly improve oxygen consumption, have other benefits such as enhanced flexibility and overall psychological well-being [5]. Furthermore, they enhance immunity, improve pos-tural stability and reduce spinal cord abnormalities.

Determinants and consequences of participation in the above-mentioned forms of physical activity, i.e. Pilates, yoga and tai chi, have not been widely analysed in Poland yet. Previous studies focused on one of the forms of physical activity only. The question arises, if participation in strengthening and relaxation exercises encourages participants to take pro-health measures and to take part in them systematically to a different extent than other forms of physical activity. Contemporary forms of fitness are gaining popularity and they have all one aim in common - achieving unity of the body and mind and enhancing control over psychomotor skills. Defining their subjective value to participants will broaden our knowledge about their health benefits, which might be conducive to planning pro-health courses for both genders and various age groups. 


\section{MATERIALS AND METHODS}

The participant group comprised 113 women, of whom 70 took part in such strengthening and relaxation exercises as yoga, Pilates and tai chi. The control group consisted of 43 women, who did not take part in any form of physical activity. Interviewees were assigned to the groups according to the two following criteria. Firstly, women ticked in their forms if they were active and took part in various forms of physical activity. Secondly, a scale developed by Prochaska and di Clemente, which defines stages of behavioural change for adopting physical activity, was used. The model clearly delineates two stages of change - contemplation and action. The first one includes intense pondering about one's own physical activity, from a fixed state - I am not very active and I am not going to change it soon, to the readiness to make changes, e.g. from the next month on. The second stage means taking actions. At the early stage participation in classes is irregular and with time and occasional lapses (less frequent participation) it turns into participation on a regular basis [6].

Among inactive women the contemplation stage is clearly visible - they want to introduce some changes to their lives but in further future. Among active respondents a numerous group consists of women who consciously had been taking part in classes for a long time. There are also some participants describing themselves as active but practising not often enough. Detailed information is to be found in Table 1.

Table 1. Stages of behavioural change for adopting physical activity (Prohaska and DiClemente) (\%)

\begin{tabular}{lcc} 
Choice & Inactive & Active \\
\hline I am not very active and I am not going to change it soon & 35 & 0 \\
\hline I am not very active but maybe I will change it next month & 44 & 6 \\
\hline I am not very active but I am going to change it from next month & 16 & 9 \\
\hline I have been active for a short time (for 6 months) & 0 & 14 \\
\hline I have been active for more than 6 months & 0 & 14 \\
\hline I was active a year ago but I have been less active over the last few months & 0 & 16 \\
\hline I have been active for many years and I am not going to change it & 0 & 29 \\
\hline I do not know how to evaluate my physical activity & 5 & 13 \\
\hline
\end{tabular}

The assignment of groups was deliberate. Selection criteria were participation in particular forms of physical activity and the respondents' age. Furthermore, the place of residence and the experience of the instructor leading the course were taken into consideration. Active women took part in strengthening and relaxation courses which were led by instructors with at least 5 years of experience.

The group consisted of female respondents aged 40 to 55 . The average age of inactive women was 47 and of active women 49; the difference is not statistically significant. Participants lived in or close to Warsaw, in villages, cities with up to 100,000 inhabitants and in cities with a popu-lation of more than 100,000. The Central Statistical Office of Poland [7] divides towns and cities according to the number of inhabitants into towns with less than 20,000 inhabitants, middle-sized cities with up to 100,000 inhabitants and big cities with more than 100,000 inhabitants. Taking into consideration opinions on physical 
activity in cities with less and more than 100,000 inhabitants, this characteristic of the test group was chosen [6]. Material for the analysis was collected via a survey prepared by the researchers. The full questionnaire consisted of 43 questions. Yet, for the purpose of this study 19 questions were selected in order to compare the two groups. The majority of questions were close-ended items with either one or multiple correct answers with Likert scale. The questionnaire included only 2 open questions on the motivation for physical activity and activity performed together with parents in the past. Further questions pertained to barriers impeding physical activity and subjective evaluation of health behaviour. The chi-squared test in the algorithmic version was used for qualitative variables. The level of significance is $\mathrm{p}<0.05$.

\section{RESULTS}

Cultural patterns, which convey ways of spending free time, often have an influence on the decision to adopt physical activity by adults. Physical activity socialization takes places among peers, at school and at home. 35\% of active women firmly claim to have been involved in physical activity with their parents. $49 \%$ of inactive respondents state that they were rather not or firmly not active with their parents in the past. No significant differences between the declarations were noticed. Both groups name the same forms of physical activity, which they performed with their parents. Most common examples were: riding a bike (33\%), walking (22\%) and swimming (16\%). Active individuals (69\%) more often than inactive ones (49\%) took part in such after-school activities as: School Sports Clubs or Students Sports Clubs, which were organised by the school. No significant differences between the declarations were noticed.

Motives and needs, which determine a healthy lifestyle, are salient factors describing a test group. Health factors - disease and pain - are the most frequent ones, which would drive inactive respondents to physical activity (31\%). Further vital factors are overweight and obesity (28\%). Most active interviewees point to deteriorating mobility (18\%) and (as in the inactive group) the risk of overweight and obesity (13\%) as factors which bring them to physical activity.

Respondents most often list healthy nutrition behaviour, physical activity and keeping a proper weight as factors influencing their health. Significantly more frequently active individuals enumerate exercising and environment as the main parts of human health (Table 2). A statistical difference at the level $\mathrm{p}<0.05$ was noted between the declarations. $83 \%$ of participants of strengthening and relaxation classes claim that their physical activity is beneficial to their health and encourages them to lead a "healthy lifestyle".

Interviewees defined individual factors leading to overweight and obesity. Active women claim to lead a healthy lifestyle. According to both active and inactive respondents, inappropriate dietary behaviour is the most frequent factor leading to a rapid weight gain. Further factors are connected with genetics and proper metabolism (Table 3). 
Passive lifestyle and long-term passivity can significantly influence human health, which both active and inactive individuals (55\%) are aware of. Another factor affecting health is stress. The pace of life and work overload were most frequently named by the respondents (Table 4). No significant differences between the declarations were noticed.

As far as a preventive effect of physical activity is concerned, active and inactive women point to cardiac diseases (heart attack and hypertension) (Table $5)$.

Physical activity plays a key role in preventing involution of motor skills and improves mobili-ty as people age. A vast majority (77\%) of interviewees (active and inactive) claim that physical activity can be conducive to ageing in a better and more active way and it makes everyday activities easier.

Awareness of the value and the positive impact of physical activity on an ageing body is prominent. Both groups claim that it enhances their self-reliance in moving and doing daily chores (shopping, preparing meals). Respondents highly value a positive influence of physical activity on dealing with everyday difficulties such as steps and obstacles and they underscore their independence of other people. As the last factor they list a possibility to participate in local community life, e.g. seniors clubs, where they can spend time together with their peers. In the case of all answers active respondents were more often firmly convinced (most notes 5 on a scale 1-5) that it is neces-sary to take up physical activity when getting old (Table 6).

Promoting healthy lifestyle through establishing one's own ways of spending free time is relevant, in particular for specialists of recreational physical activity and advocates of healthy lifestyle in various environments. Their components are: pro-health campaigns, an appropriate amount of exercises, using supplements and a correlation between physical activity and health. Both groups do not perceive physicians as a reliable source of information on benefits of physical activity (active respondents gave a negative opinion more often). Risk of overweight and obesity is a vital factor for both groups as active and inactive interviewees recognise gaining weight as a significant health hazard. It is also crucial how interviewees from both groups evaluate the amount of performed physical activity. Both active and inactive respondents claim that the amount is insufficient (Table 7).

Table 2. The most crucial factors influencing health according to the respondents (\%)

\begin{tabular}{lcc}
\hline Choice & Inactive & Active \\
\hline Propernutrition & 84 & 91 \\
\hline Proper body weight & 47 & 59 \\
\hline Limitation of the stimulants (alcohol, cigarettes) & 51 & 44 \\
\hline Natural environment & 14 & 31 \\
\hline Adoption of physical activity & 47 & 74 \\
\hline Avoiding stressful situations & 37 & 49 \\
\hline Genetic predispositions & 21 & 33 \\
\hline Support from family, friends & 12 & 23 \\
\hline Others & 2 & 3 \\
\hline
\end{tabular}


Table 3. The most crucial factors influencing weight gain according to the respondents (\%)

\begin{tabular}{lc} 
Choice & Active and inactivegroup \\
\hline Inappropriate dietary behaviour & 30 \\
\hline Genetic and metabolism & 22 \\
\hline Fatcontent in food & 20 \\
\hline Sugarcontent in food & 20 \\
\hline Appropriate amount of physical exercises & 5 \\
\hline Alcohol & 2 \\
\hline Smoking & 1 \\
\hline
\end{tabular}

Table 4. Stressful factors according to the respondents (\%)

\begin{tabular}{ll}
\hline Choice & Active and inactive group \\
\hline Stress connected to pace of life & 28 \\
\hline Work overload & 22 \\
\hline Overload of home duties & 18 \\
\hline Bad material situation & 14 \\
\hline Problems with children/husband & 12 \\
\hline None of the abovementioned & 5 \\
\hline Others & 1 \\
\hline
\end{tabular}

Table 5. Preventive meaning of the physical activity according to the respondents (\%)

\begin{tabular}{lcc}
\hline Choice & Active & Inactive \\
\hline Heart attack & 49 & 58 \\
\hline Hypertension & 43 & 44 \\
\hline Chronic fatigue & 31 & 23 \\
\hline Depression & 26 & 28 \\
\hline Diabetes & 19 & 26 \\
\hline Arteriosclerosis & 14 & 26 \\
\hline Osteoporosis & 17 & 9 \\
\hline Different addictions & 1 & 5 \\
\hline
\end{tabular}

Table 6. Preventive meaning of the physical activity according to the respondents (\%)

\begin{tabular}{lll}
\hline The average of answers (scale: 1-5) & Inactive & Active \\
\hline Self-reliance (shopping, preparing meals) & 4.6 & 4.6 \\
\hline Dealing with everyday difficulties (e.g. steps and obstacles) & 4.5 & 4.6 \\
\hline Possibility to participate in local community life (e.g. seniors clubs) & 4.3 & 4.4 \\
\hline Independence of other people & 4.4 & 4.5 \\
\hline
\end{tabular}

Table 7. Preventive meaning of the physical activity according to the respondents (\%)

\begin{tabular}{lll}
\hline The average of answers (scale: 1-5) & Inactive & Active \\
\hline Physical activity has a positive impact on health & 4.5 & 4.7 \\
\hline If I was 13 kg heavier, it would be risky for my health & 4.0 & 4.0 \\
\hline The only benefit of physical activity is a possibility to lose weight & 1.5 & 1.4 \\
\hline The amount of physical activity that I adopt is enough & 2.5 & 2.7 \\
\hline Many of my friends adopt a lot of physical activity & 2.3 & 2.6 \\
\hline $\begin{array}{l}\text { The doctors are a good source of information about the benefits of the physical } \\
\text { activity and its pro-health values }\end{array}$ & 3.1 & 2.4 \\
\hline $\begin{array}{l}\text { A pro-health campaign run in my city would have an influence on the enhancement } \\
\text { of my physical activity }\end{array}$ & 3.0 & 3.1
\end{tabular}




\section{DISCUSSION}

The topic of well-being, in particular among older individuals [8], has been recently gaining in popularity. Many philosophical, spiritual, and psychological traditions emphasize the importance of the quality of consciousness for the maintenance and enhancement of well-being [37]. Such factors enhancing health and the quality of life as physical activity and healthy nutrition play a key role.

Furthermore, awareness-raising activities prepare individuals to consciously and voluntarily pursue physical fitness on a regular basis. Physical fitness can be treated not only as a significant aspect of the individual's health and the basis for achievements in sports but also a determinant of self-reliance in situations pertaining to everyday activities such as washing, getting dressed or preparing meals. Due to the changing perception of physical fitness, the term itself has evolved recently. Programmes promoting physical fitness and its evaluation have also undergone changes. Physical fitness ceased to be attributed to motor performance or skill-related components and started to be distinguished from them [38]. Physical fitness pertains to cardiopulmonary functions, body composition, muscular strength and endurance as well as to flexibility. The aforementioned elements are thought to be directly linked to higher life quality [38]. Furthermore, they are perceived to be vital for prevention of most health problems. Health-related fitness is defined as physical and physiological organism's characteristics, which indicate the risk level of the premature development of diseases due to a sedentary lifestyle [39]. Health-related fitness pertains to fitness components which stem from the positive and negative impact of everyday fitness activity and its influence on health. They are described as the ability to perform everyday exercises vigorously and enthusiastically [40, 41].

The study conducted by Ignasiak [8] shows that the majority of respondents are active people, who eagerly attend sport and recreational classes. Among inactive individuals, more often women than men, laziness was the main reason for the lack of interest in active lifestyle. Lack of time and bad health were factors discouraging people from activity. Furthermore, studies show that ca. $20 \%$ of respondents do not see the need to take up physical activity. The study conducted by Schutzer and Graves [42] also points out that although exercise is an established component in the management of many chronic diseases associated with aging, activity levels tend to progressively decline with increasing age.

WHO recommends 30 minutes of moderate exercises 5 times a week or 20 minutes of vigorous physical activity 3 times a week. Numerous studies [9, $10,11,12]$ show that citizens of the European Union do not stick to the optimal recommended time of physical activity. It is becoming more and more perceivable in Poland. On the other hand, various studies suggest that regular moderate physical activity can be health-enhancing. It can reduce the risk of premature death, dia-betes, hypertension and gaining weight [13]. Research conducted in the European Union [14] shows that $40-80 \%$ of people lead a sedentary lifestyle: the highest percentage of inactive people (women and men) is in Portugal, in Poland the biggest group of inactive individuals live in Lodz. Studies carried out by Malaczynska-Rajpold [15], which examined ac- 
tive and inactive people, prove a lower percentage of body fat in active people. Furthermore, studies confirm increased visceral fat in inactive people in comparison to active people, which can result in visceral obesity leading to cardio-vascular diseases [15]. Physical activity is often perceived as a factor reducing cardiovascular diseases and as an element of a healthy lifestyle, which has been corroborated by answers given by the respondent of this study on preventive healthcare and its influence on the non-communicable diseases of the 21st century. The research of Warburton et al. [47] confirms that there is a lot of evidence of the effectiveness of regular physical activity in the primary and secondary prevention of several chronic diseases (e.g., cardiovascular disease, diabetes, cancer, hypertension, obesity, depression and osteoporosis) and premature death. There appears to be a linear relation between physical activity and the health status, such that a further increase in physical activity and fitness will lead to additional improvements in the health status.

Studies conducted by Zagroba [16] show that a vast majority of respondents (ca. 90\%) performing various forms of physical activity are aware of their health benefits. Respondents of the two groups of this study shared a similar opinion.

Regular physical activity is strongly associated with better physical and psychological health outcomes, and the promotion of physical activity is now a high public health priority [46]. To develop relevant policies and effective interventions, it is necessary to identify the factors that can be changed to influence physical activity behaviour [45]. Such factors have been classified within seven domains: demographic and biological, psychological, cognitive and emotional, behavioural attributes and skills, social and cultural, physical environmental, and physical activity characteristics (perceived effort and intensity) [45]. According to Pelc [17], a healthy lifestyle among women means proper dietary behaviour, workplace health, rest, stress management and physical activity. Based on the results of Zarow and Matusik [18], researchers made a few significant conclusions. Physical activity taken up by women has a vital pro-health influence, in particular as far as maintaining or im-proving well-being and motor skills is concerned. The above-mentioned conclusions have been corroborated by this research as our respondents name proper nutrition practices and physical activity as the most significant factors influencing health. They point to wrong dietary behaviours as a serious threat of excessive weight gain.

Motives and needs are crucial in adopting regular physical activity. Studies led by Alejziak [19] showed that for over 50\% of women of Tarnow (Poland) the most important factors driving them to lead of a healthy lifestyle were shaping their body and boosting their appearance as well as improv-ing their well-being. Surveyed students [20] and women aged 16 to 60 [21] put preventive healthcare on the first position. Furthermore, women who do not feel the need to exercise take up physical activity solely for health reasons, which has been further corroborated by this study. Adults with type 2 diabetes (men and women) reported intrinsic motives such as enjoyment, interest, fun, stimulation and highlighted gender differences after having undertaken regular physical activity. Female participants were more likely than male participants to emphasise the importance of emotional support obtained from group meetings, and the pleasure of doing something together, and male participants emphasised 
knowledge acquisition and skill development for disease control. Moreover, female participants indicated the importance of the sense of well-being and the positive body image related to regular physical activity, and male participants underlined the strength of the relationship between physical activity and health-promoting behaviours [48].

Results of our study prove that adopting physical activity has a pro-health meaning for active and inactive respondents - especially in order to preserve mobility in the old age. Studies conducted by Muszalik and Kedziora-Kornatowska [22] show that elder individuals and people suffering from chronic diseases (diabetes, hypertension, coronary artery disease, chronic heart failure, diseases of the musculoskeletal system and chronic kidney disease) most often informed about reduced mobility, reduction of life force, sleeping disorders and pain. Therefore, adopting systematic and proper physical activity has a vital pro-health role for this age group. Studies led by Szczepanska [23] prove that increasingly more elder individuals value physical activity as it relieves pain and enhances psychological and physical fitness, which has been corroborated by the respondents of our study. According to Corbin [24], physical activity, in particular tai chi, adopted by older individuals (over 65 years old) improves their posture and boosts physical and psychological comfort since it improves flexibility of muscles and tendons, stretches joints and strengthens muscle groups. These findings have been supported by studies conducted by Li et al. [25]. A 6-month tai chi programme involving 256 inactive adults aged 70 to 92 proved to be effective to decrease the number of falls and reduce the risk of falling. Additionally, the fear of falling among respondents dropped. Lan's study [26] underscores that 12-month tai chi training has a beneficial influence on health fitness of the elderly. Findings show an increase in lumbar flexibility, muscle strength of the knee extensor and of the knee flexor among women as well as men. The control group (inactive participants) showed no significant changes as far as these variables are concerned. A study by Grabara and Szopa [27] confirms the essential pro-health effect of yoga classes on seniors. Findings show that women and men aged 65 to 85 who practiced hatha yoga improved their flexibility while bending forward, and their balance as well as their well-being was boosted. In comparison to the control group, who walked or did not exercise at all, active participants noticed subjectively enhanced life force. The above-mentioned exercises effectively prevent elderly individuals from falling as practiced movements enhance flexibility of joints, improve balance and body posture and strengthen legs. Studied carried out by Pyatkov [28] and Krol and Maszorek-Szymala [3] confirm that regular yoga classes boost physical and psychological well-being, improve patience and persistence in pursuing one's aims. Moreover, they reduce pain and improve psycho-physical functions [29].

Sorosky et al. [43] compared efficacy of yoga and Pilates classes in managing low back pain and underscored that these two exercise interventions improve core strength, flexibility, and relaxation. Both exercise modes are recommended in particular to patients with chronic low back pain. Caldwell et al. [44] compared such methods of exercise as Pilates and taiji quan (tai chi) with the control group attending recreational classes and came to some vital conclusions. No differences were discerned between the strength and balance measures of the three groups. The Pilates group noted the greatest improvement in positive mood understood as positive energy, whereas the 
taiji group achieved higher relaxation scores. Respondents from the Pilates and taiji groups reported a decrease in negative mood in the middle of the experiment. Yet, by the end of the experiment they returned to the starting levels. The taiji group noted the biggest increase in self-efficacy at the end of the experiment. Self-regulatory scores of both the taiji quan and the control group were similar, whereas the Pilates group showed a significant increase in self-regulation at the end of the experiment and a vital increase in comparison to the control group. Both the taiji quan and Pilates groups significantly improved their sleep quality. Yet, no differences between the groups were discerned. The research indicates that Pilates and taiji quan classes can have a crucial effect on the physical and psychological health.

Physical activity is an inextricable part of a healthy lifestyle. Interviewed women are aware of the benefits of physical activity, in particular regarding improved mobility. Penedo and Dahn [30] suggest that exercises, physical activity and physical-activity interventions have beneficial effects across several physical and mental-health outcomes. Generally, participants engaged in regular physical activity display more desirable health outcomes across a variety of physical conditions. Similarly, participants show better health outcomes, including better general and health-related quality of life, better functional capacity and better mood states.

Selected forms of physical activity such as Pilates, yoga and tai chi play an essential role in building physical and psychological fitness. They are based on a holistic health approach and seek inner harmony [2]. Studies conducted by Mazur and Marczewski [31] underscore that 3-month Pilates training led to a perceived improvement in the health status, pain reduction and improved concentration skills. Furthermore, a slight yet visible reduction of the perimeter of the buttocks, thighs, lower legs and shoulders was observed. These exercises have a salient influence on participants' health with e.g. chronic back pain, as they improve muscle strength and endurance [32]. They also boost mobility [33], regulate blood pressure and influence body mass - they reduce BMI even within 4-week training [34] thus, such exercises can prevent obesity.

Performing various forms of physical activity has a beneficial influence on psycho-physiological well-being. Having tested women aged 42 to 70 , we can confirm that physical activity is an important part of the pro-health behaviour, as it has a health-enhancing, preventive, rehabilitating and therapeutic effect [35]. Due to regular exercises, participants significantly improved their mobility and motor skills, reduced stress and enhanced life quality thanks to positive emotions experienced while practising. In addition, physical activity can boost mood. Active individuals not only notice improved physical fitness but also an increase in energy and a reduction of muscle tension [22]. Studies carried out by Zagroba et al. [36] point to pro-health effects of physical activity which prevent obesity, reduce stress and tensions, improve oxygen consumption and body posture. Furthermore, physical activity plays a key psychological role - it is conducive to meeting new people, improves mood and socialization. Raising awareness of the society has an essential influence on the lifestyle. More and more often women adopt physical and recreational activities due to their health-enhancing effects. 


\section{CONCLUSIONS}

1. The results of our study prove that the respondents notice the pro-health impact of physical activity and name it mostly as the most significant factor influencing health.

2. In comparison with other forms of physical activity, no significant differences con-cerning Pilates, yoga and tai chi in the respondents' opinion have been noticed.

3. These classes have a beneficial influence on health and psycho-physiological well-being. There is an evident need to seek deeper pro-health connections that have an influence on the holistic approach to the above mentioned forms, namely: biological, psychological and social ones.

\section{REFERENCES}

[1] Wlostowska K. Postawy prozdrowotne studentow uczelni wychowania fizycznego [Health attitudes in students of physical education universities]. In: Bulicz E, editor. Potegowanie zdrowia: czynniki, mechanizmy i strategie zdrowotne [Multiplying health, mechanisms and health strate-gies]. Radom: Wydawnictwo i Zaklad Poligrafii ITE; 2003, 257-261. Polish.

[2] Gavin J. Pilates. Energia, fitness i zgrabna sylwetka [Energy, fitness and slender silhouette]. UK: Parragon Books Ltd.; 2006. Polish.

[3] Krol K, Maszorek-Szymala A. Aktywnosc ruchowa dojrzalych kobiet - moda czy koniecznosc [Physical activity of mature women - fashion or necessity]. Wychowanie Fizyczne i Zdrowotne. 2010;57:30-33. Polish.

[4] Korzeniewska I. Cwiczenia pilates [Pilates exercises]. Wychowanie Fizyczne i Zdrowotne. 2004;11:13-15. Polish.

[5] Rydeard R, Leger A, Smith D. Pilates-based therapeutic exercise: effect on subjects with non-specific chronic low back pain and functional disability: a randomized controlled trial. JOSPT. 2006;36(7):472-484.

[6] Mogila-Lisowska J. Rekreacyjna aktywnosc ruchowa doroslych Polakow - uwarunkowania i styl uczestnictwa [Recreational physical activity of adult Poles - conditions and patterns]. Warszawa: AWF; 2010. Polish.

[7] Statistical yearbook of the republic of Poland 2009 - [Available at www. stat.gov.pl] [Accessed on 10 September, 2014].

[8] Ignasiak Z, Slawinska T, Krynicka-Pieleszek I, Domaradzki J. Aktywnosc fizyczna doroslych wroclawian [Physical activity of adult inhibitors of Wroclaw, Poland]. Fizjoterapia. 2009;17(2):33-37. Polish.

[9] Manson JE, Skerrett PJ, Greenland P, VanItallie TB. The escalating pandemics of obesity and sedentary life style. A call to action for clinicians. Archives of Internal Medicine. 2004;164:249-58.

[10] Blair S, Cheng Y, Holder J. Is physical activity or physical fitness more important in defining health benefits? Med Sci Sport Exerc. 2001;33:379.

[11] Jakicic JM, Otto AD. Treatment and prevention of obesity: what is the role of exercise? Nutrition Reviews. 2006;64:57-61.

[12] Leon AC, Rodriguez-Perez M, Rodriguez-Benjumeda L. et al. Sedentary lifestyle: Physical activity duration versus percentage of energy expenditure. Revista Espanola De Cardiologia. 2007;60:244.

[13] Krzysztofiak H, Mamcarz A. Aktywnosc fizyczna w profilaktyce choroby niedokrwiennej serca - recepta na wysilek [Physical activity in cardiac diseases prophylaxix]. Kardiologia w Praktyce. 2007;1(39):265277. Polish.

[14] Slawek M, Sleboda R. Joga i jej wartosci w ksztaltowaniu zdrowego stylu zycia. Uniwersytet Szczecinski [Yoga and its advantages in creating a helath life-style]. Zeszyty Naukowe 2011;689(78):153-166. Polish.

[15] Malaczynska-Rajpold K, Woznicka L, Kuczmarska A, Janura J, Lipska I. Aktywnosc fizyczna jako czynnik redukujacy ryzyko sercowo-naczyniowe w populacji badanej w programie „Kobiety w czerwieni” [Physical activity as a factor reducing a cardiovascular risk in the population examined in "Women in red” Programme]. Nadcisnienie Tetnicze. 2009;13(1):42-47. Polish.

[16] Wojtczak A. Zdrowie publiczne wzywaniem dla systemow opieki zdrowia XXI wieku [public health as a challenge for health care systems in 21st century]. Warszawa: Wydawnictwo Lekarskie PZWL; 2009. Polish.

[17] Myrna-Bekas R, Lisowska K. Udzial w wybranych formach aerobiku a uzyskiwany poziom nastroju uczestniczek zajec [Participation in chosen forms of aerobics vs obtained level of a mood]. Rozprawy Naukowe AWF Wroclaw. 2009;29:674-678. Polish.

[18] Zarow R, Matusik S. Women's sport's and recreational activity in relation physical efficiency. Annales Universitatis Marie Curie-Sklodowska Lublin-Polonia. 2005;673:468-472.

[19] Alejziak B. Fitness as an active form of spending free time by women of Tarnow. Zeszyty Naukowe Malopolskiej Wyzszej Szkoly Ekonomicznej w Tarnowie. Prace z Zakresu Zarzadzania. 2011;17(1):11-28.

[20] Wilk B. Rekreacja fizyczna kobiet w trosce o zdrowie [Physical recreation of women as a health issue]. Annales Universitatis Marie Curie-Sklodowska Lublin-Polonia. 2005;616:229-231. Polish. 
[21] Pelc Z. Systematyczna aktywnosc ruchowa podstawa zdrowego stylu zycia [A systematic physical activity as a basis of healthy life-style]. In: Sladkowski Z, editor. Model zdrowego stylu zycia jako zadanie interdyscyplinarne [A model of health life-style]. Annales Universitatis Marie Curie-Sklodowska AM Lublin. 2003;399-445. Polish.

[22] Muszalik M, Kedziora-Kornatowska K. Jakosc zycia przewlekle chorych pacjentow w starszym wieku [Quality of life in seniors suffering from chronic diseases]. Gerontologia Polska. 2006;14(4):185-189. Polish.

[23] 23. Szczepanska B, Szady-Grad M, Klawe JJ, Kolodziejska K, Zaworska L. Ogolnopolskie badania jakosci zycia zwiazanej ze zdrowiem fizycznym i psychicznym kobiet w wieku 45-60 lat. Cz. 3. Badania kobiet z wojewodztwa kujawsko-pomorskiego [Polish research on quality of life con-nected with mental and physical health in women aged 45-60 from Kujawsko-Pomorskie voi-vodeship]. Problemy Higieny i Epidemiologii. 2009;90(4):506-510. Polish.

[24] Corbin CB, Welk GJ, Corbin WR, Welk KA. Fitness i wellness. Kondycja, sprawność, zdrowie [Fitness and wellness. Trim, fitness and health]. Poznań: Wydawnictwo Zysk S-Ska; 2007. Polish.

[25] Li F, Harmer P, Fisher KJ, et al. Tai Chi and Fall Reductions in Older Adults: A Randomized Controlled Trial. The Journals of Gerontology: Series A. 2005;60(2):187-194.

[26] Lan C, Lai JS, Chen SY, Wong MK. 12-month Tai Chi training in the elderly: its effect on health fitness. Medicine and Science in Sports and Exercise. 1998;30(3):345-351.

[27] Grabara M, Szopa J. Wplyw uczestnictwa w programach prozdrowotnych opartych na systemie cwiczen hatha jogi na zdrowie i sprawnosc osob doroslych i seniorow [Impact of participating in pro-health programmes based on hatha yoga on health and fitness in adults and seniors]. Zeszyty Naukowe Alma Mer. 2012;1(65):101-112. Polish.

[28] Poliszczuk T, Tkaczyk W. Wplyw aktywnosci ruchowej na sprawnosc fizyczna kobiet w rownym wieku uczeszczajacych na zajecia z aerobiku [Impact of physical activity on physical fitness in women at various age practicing aerobics]. In Bulicz E, editor. Potegowanie zdrowia: czynniki, mechanizmy i strategie zdrowotne [Multiplying health, mechanisms and health strategies]. Radom: Wydawnictwo i Zaklad Poligrafii ITE; 2003; 364- 368. Polish.

[29] 29. Sandlund ES, Norlander T. The Effects of Tai Chi Chuan Relaxation and Exercise on Stress Responses and Well-Being: An Overview of Research. International Journal of Stress Management. 2000;7(2):139149.

[30] Penedo FJ Dahn, JR. Exercise and well-being: a review of mental and physical health benefits associated with physical activity. Current Opinion in Psychiatry. 2005;18(2):189-193.

[31] Mazur A, Marczewski K. Subiektywna ocena zdrowia u kobiet po 3 miesiacach stosowania cwiczen metoda Pilatesa [Subjective evaluation of health in women after 3-month Pilates exercises]. Zamojskie Studia i Materialy. 2011;1(34):34-43. Polish.

[32] Pyatkov V, Bilinski J, Gwozdz M. Zdrowotne aspekty cwiczen fizycznych na przykladzie jogi [Health aspects of physical exercises on example of yoga]. Sportivnaya Nauka Ukrainy. 2011;6:12-26. Polish.

[33] Lange C, Unnithan VB, Larkam E, Latta PM. Maximizing the benefits of Pilates-inspired exercise for learning functional motor skill. Journal of Bodywork and Movement Therapies. 2000;4(2):99-108.

[34] Jago R, Jonker ML, Missaghian M, Baranowski T. Effect of 4 weeks of Pilates on the body composition of young girls. Preventive Medicine. 2006;42(3):177-180.

[35] Stelmach M. Rola aktywnosci fizycznej w profilaktyce otylosci oraz innych przewleklych chorob niezakaznych [The role of physical activity in obesity and other non-contagious diseases prophy-laxis]. Czlowiek i Zdrowie. 2010;1(4):50-58. Polish.

[36] Zagroba M, Kulikowska A, Marcysiak M, Wisniewska E, Ostrowska B, Skotnicka-Klonowicz G. Aktywnosc fizyczna pielegniarek [Physical activity in nurses]. Problemy Pielegniarstwa. 2010; 18 (3): 329-336. Polish.

[37] Wilber, K. Integral psychology: Consciousness, spirit, psychology, therapy. Boston: Shambhala; 2000.

[38] Osinski W. Metody diagnostyczno-ewaluacyjne [Diagnostic and evaluational methods]. In: Kowalik S, editor. Kultura fizyczna osob z niepelnosprawnoscia. Dostosowana aktywnosc ruchowa [Physical culture of disabled. Adapted physical activity]. Sopot: Gdanskie Wydawnictwo Psychologiczne; 2009. Polish.

[39] Sas-Nowosielski K. Wychowanie do aktywnosci fizycznej [Upbringing for physical activity]. Katowice: AWF; 2003. Polish.

[40] Osinski W. Antropomotoryka [Anthropomotorics]. Poznan: AWF; 2003. Polish.

[41] Skinner JS, Oja P. Laboratory and field tests for assessing health-related fitness. In: Bouchard C, Shephard RJ, Stephens T, editors. Physical activity, fitness and health. Champaign IL: Human Kinetics Publishers. 1994; 160-179.

[42] Schutzer KA, Graves BS. Barriers and motivations to exercise in older adults. Preventive Medi-cine. 2004;39(5):1056-1061.

[43] Sorosky S, Stilp S, Akuthota V. Yoga and Pilates in the management of low back pain. Current Reviews in Musculoskeletal Medicine. 2008;1:39-47.

[44] Caldwell K, Harrison M, Adams M, Triplett NT. Effect of Pilates and taiji quan training on self-efficacy, sleep quality, mood, and physical performance of college students. Journal of Body-Work and Movement Therapies. 2009;13:155-163

[45] Dishman RK, Sallis JF, Determinants and interventions for physical activity and exercise, In Bouchard C, Shephard RJ, Stephens T, editors. Physical activity, fitness, and health, international proceedings and consensus statement, Champaign GA: Human Kinetics. 1994; 214-238.

[46] U.S. Department of Health and Human Services, Physical activity and health a report of the Surgeon General, U.S. Department of Health and Human Services. Centers for Disease Control and Prevention, National Center for Chronic Disease Prevention and Health Promotion. Atlanta: GA; 1996. 
[47] Warburton DER, Nicol CW, Bredin SSD. Health benefits of physical activity: the evidence. CMAJ. 2006;174(6):801-809.

[48] Ferrand C, Perrin C, Nasarre S. Motives for regular physical activity in women and men: a qualitative study in French adults with type 2 diabetes, belonging to a patients' association. Health and Social Care in the Community. 2008;6(5):511-520. 